\author{
Sławoj Tanaś \\ University of Łódź \\ Instytut of Urban Geography and Tourism Studies \\ slatan@geo.uni.lodz.pl
}

\title{
THE MEANING OF GENOCIDE AND TERROR IN COGNITIVE TOURISM
}

\begin{abstract}
The article considers the influence of acts of terror and war crimes on both the development of tourism, or a lack of it. Terrorist attacks, the victims of which are tourists as well as local citizens, constrain or completely prevent tourism development. Terrorism is then a barrier to the development of the tourism economy. With time, however, memory of the crime and its victims, due to documentation and commemoration, may become an impulse to organize spaces which will be included in tourism.
\end{abstract}

Key words: thanatourism, terrorism, genocide, remembrance, tourism space.

\section{INTRODUCTION}

Information plays an important role in creating tourism needs and motivations often differing from those in the past. Let us take, for example, travelling to places which in the mid-20 $0^{\text {th }} \mathrm{c}$. were regarded as nontouristic for safety reasons, lack of tourism infrastructure and facilities, and political or transport limitations.

The 1980s marked the beginning of travel to sites where acts of terror or war crimes had taken place in the relatively recent past. Although visiting sites of terror, genocide or war has a long history, trips made in order to see the site of a crime still vividly remembered by local people and stirring strong emotions among them, have always been controversial (SHARPLEY \& STONE 2009, STONE 2012). The urge for this type of travel may arise from a variety of reasons, such as the need to pay homage to the victims, a feeling of empathy towards them or their relatives, or the need to commemorate the very fact of the crime itself. Tourists' needs, however, may be purely emotional, e.g. they may want to travel to a site which has experienced evil and cruelty, and bears the stigma of the dangerous or forbidden, evoking fear and disgust. Such tourism is most often referred to as dark tourism (LENNON \& FOLEY 2000) and thanatourism (SEATON 1996). The literature offers a whole array of terms describing journeys to sites with a sinister history, such as black spot tourism, slavery tourism, genocide tourism, war tourism, battlefield tourism, terror tourism, phoenix tourism or death tourism.
Armed conflicts and terrorism belong to those factors which constrain or prevent tourism. Other factors are social (crime rate, cultural differences), political (political or religious conflicts), health (epidemics, contagious diseases), industrial (chemical and nuclear hazards) and environmental (natural disasters). The main causes are the impossibility of guaranteeing safety to tourists and those employed in the industry, as well as the logistical difficulties in organizing a tourism stay in dangerous areas.

The factors constraining tourism development also include ethical barriers (STONE 2012). Should an exploring tourist visit places where other people have suffered and died, and at the same time observe the results of violence; and not necessarily combining their stay with a noble cause such as humanitarian aid?

For safety or political reasons, in such situations, tourists are usually isolated from the world around them and safely accommodated; they travel in convoys guarded by armed police, the army or special units, and observe reality from a 'safe' though close distance. In such circumstances we may even talk about the theatricalisation of human suffering.

In the contemporary world, tourism is considered to be one of the most profitable sectors of an economy. In 2012, it generated $9 \%$ of global GNP and $6 \%$ of exports in the least developed countries, bringing in 1,200 billion dollars annually, with 1,035 billion tourism arrivals crossing borders. One in 12 jobs 
globally is found in the tourism sector. Compared to the previous year, in 2012 the increase in the number of foreign tourism arrivals was larger in developing countries $(+4.3 \%)$. In Africa, it reached 6\%, after a considerable drop of $9 \%$ in 2011 due to unrest in North Africa. In 2011, there was a clear decrease in the number of arrivals in Tunisia $(-31 \%)$ and Egypt $(-32 \%)$, in comparison to 2010. Again, it was a consequence of political unrest and acts of violence. A similar trend was found in 2011 in Jordan (-6\%), Lebanon $(-24 \%)$, Palestine $(-14 \%)$ and Syria $(-41 \%)$ (UNWTO 2012, 2013).

Tourism is one of the key economic sectors in many countries, in particular those with an unstable socio-political situation and underdeveloped economy, countries which are nevertheless attractive from the point of view of satisfying tourism needs. Statistics concerning foreign tourism arrivals in 2011 and 2012 in South Africa alone show how sensitive tourism is to political unrest and a lack of security resulting from terrorist, military and criminal activity.

Acts of violence, war and terrorism limit tourism over relatively short periods. The changes in tourism in South-East Asia, which were the consequence of the terrorist attack on the World Trade Centre (WTC) in New York in 2001, were pointed out by EDMONDS \& MAK (2006) who showed that tourism decreases only for a short period of time, but returns to the previous trend. Unfortunately, it is always connected with considerable financial losses in many sectors of the economy (Fig. 1).

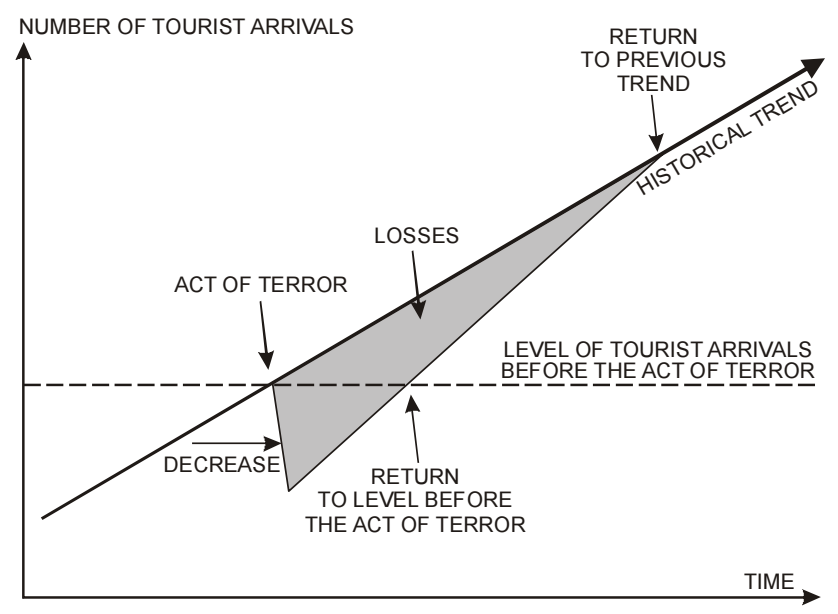

Fig. 1. Decreases and increases in tourism after an act of terror S o u r c e: author's compilation based on EDMONDS \& MAK (2006)

In the long run, acts of violence (genocide, terror) may be commemorated in geographical space through symbols - monuments, graves, museums or theme parks (historical). With time, events of this type may become an impulse to the development of a historical asset associated with an act of violence, and then be transformed gradually into a tourism attraction and product. Then we may speak about the formation of remembrance space, a symbolic space frequently visited by tourists.

\section{GENOCIDE AND TERROR AS A BARRIER TO TOURISM DEVELOPMENT}

In the second half of the $20^{\text {th }} \mathrm{c}$. and in the early $21^{\text {st }} \mathrm{c}$., in the era of rapid global economic development (including tourism), military conflicts have become very common frequently resulting in war atrocities and genocide. War discourages potential tourists, though there are cases when a 'tourist' travels to a conflict area in order to experience the reality of war directly (currently, it is the border area between North and South Korea, Syria, Afghanistan, Pakistan and Iraq).

An element relevant to this issue is the scale of today's crimes against humanity, which largely or completely prevent tourism development. Unfortunately, recent acts of genocide have been taking place in very attractive tourism areas (BEECH 2009). In the last 50 years, they have been recorded in Bangladesh, Cambodia (crimes committed by the Khmer Rouge), Northern Iraq (the Kurdish massacre), the former Yugoslavia (Srebrenica massacre), Rwanda (the conflict between the Tutsi and the Hutu), Darfur (the conflict in Sudan), Syria (civil war), and many other parts of Africa and Asia (BRUNETEAU 2005). In the literature in English on the subject, travel to places where people are killed in great numbers is referred to as genocide tourism (BEECH 2009).

In the second half of the $20^{\text {th }} \mathrm{c}$. a new military target - civilians - was used, who had nothing to do with the front line or any conscious contact with the war. Civilians, attacked in all parts of the world from the 1960s, have included tourists who have fallen victim to terrorist armed groups, partisans and criminals, kidnapping or killing for publicity, to reach their own political goals or to gain money.

Terrorism is a form of political violence, in which murder or destruction is used (or its threat) in order to shock or arouse extreme fear in individuals, or among groups, communities and authorities, to force them to agree to political compromise, provoke hasty reactions and to demonstrate their own political stand (BOLECHÓW 2002, 35). In the case of attacks on tourists, we may talk about international terrorism, involving the citizens or territory of more than one country. Religious terrorism may affect pilgrimage tourism. 
$\mathrm{T}$ a b l e 1. Examples of terrorist attacks on tourists

\begin{tabular}{|c|c|c|}
\hline Date & Place & Event description \\
\hline $5 / 3 / 1970$ & Tel Aviv (Israel) & Attack on the Savoy Hotel in Tel Aviv \\
\hline $13 / 2 / 1978$ & Sydney (Australia) & Attack on the Hilton Hotel in Sydney \\
\hline $2 / 11 / 1979$ & Mecca (Saudi Arabia) & Islamic terrorists occupy the Great Mosque in Mecca \\
\hline 26/9/1980 & Munich (Germany) & Bomb attack during the Oktoberfest \\
\hline $7 / 10 / 1985$ & Alexandria (Egypt) & Hijacking of the Achille Lauro (a ship) \\
\hline 22/9/1989 & Deal (England) & $\begin{array}{l}\text { Bomb explosion at the Royal Marines holiday centre in Deal, organized by the } \\
\text { IRA }\end{array}$ \\
\hline 18/4/1996 & Giza (Egypt) & $\begin{array}{l}\text { Islamic extremists shoot Greek tourists, taking them for Israelis, near the } \\
\text { pyramids in Giza }\end{array}$ \\
\hline $28 / 7 / 1996$ & Atlanta (USA) & Bomb explosion during a concert at the Atlanta Olympic Games \\
\hline 18/9/1997 & Cairo (Egypt) & German tourists die in an attack in front of the Egyptian Museum \\
\hline $17 / 12 / 1997$ & Luxor (Egypt) & Attack on tourists in Luxor \\
\hline $15 / 10 / 1997$ & Colombo (Sri Lanka) & Attack on the Galedan Meridian Hotel \\
\hline $11 / 9 / 2001$ & New York (USA) & Attack on the World Trade Center (WTC) \\
\hline $23-26 / 10 / 2002$ & Moscow (Russia) & Attack by Chechen terrorists on the Dubrovka Theatre, Moscow \\
\hline $28 / 10 / 2002$ & Mombasa (Kenya) & $\begin{array}{l}\text { Attack on a hotel and Israeli tourists, and an attempt to shoot a plane down in } \\
\text { Mombasa }\end{array}$ \\
\hline $12 / 10 / 2002$ & Kuta (Bali - Indonesia) & Two bomb attacks on a bar and a club \\
\hline $16 / 5 / 2003$ & Casablanca (Morocco) & Suicide attack \\
\hline $5 / 8 / 2003$ & Djakarta (Indonesia) & Bomb attack on the Marriott Hotel \\
\hline $11 / 3 / 2004$ & Madrid (Spain) & Bomb attacks on suburban trains in Madrid \\
\hline $7 / 10 / 2004$ & Taba (Egypt) & Bomb attack in Taba in Egypt \\
\hline $23 / 7 / 2005$ & Sharm El Sheikh (Egypt) & Bomb attacks in Sharm El Sheikh \\
\hline $11 / 7 / 2006$ & Srinagar, Jammu, Kashmir (India) & Bomb attacks on tourists \\
\hline $24 / 4 / 2006$ & Dahab (Egypt) & Bomb attacks in Dahab \\
\hline $31 / 12 / 2006$ & Bangkok (Thailand) & Bomb attacks in Bangkok \\
\hline 20 IX 2008 & Islamabad (Pakistan) & Explosion at the Hotel Marriott \\
\hline $26-29 / 11 / 2008$ & Bombay (India) & Attacks on hotels in the centre of Bombay \\
\hline $17 / 7 / 2009$ & Djakarta (Indonesia) & Bombs explode at the luxury Marriott and Ritz-Carlton Hotels \\
\hline $18 / 7 / 2012$ & Burgas (Bulgaria) & $\begin{array}{l}\text { Suicide attack on a coach with tourists from Israel; the bus exploded in front of } \\
\text { the airport }\end{array}$ \\
\hline
\end{tabular}

S o u r c e: author's compilation.

Domestic terrorism affects the residents of the country in which political terror is used.

Inward and outward tourism is very sensitive to political instability, e.g. wars, acts of violence, riots, coups or strikes. Examples of the bloodiest and most spectacular of terrorist attacks show that political instability is an element which destroys tourism anywhere in the world. Frequent terrorist targets are hotels, restaurants, bars, clubs or railway stations, i.e. places visited by tourists (Table 1 ). The basic aim of terrorism is to arouse fear among potential victims (often tourists or pilgrims), which directly or indirectly influences the behaviour of those threatened (Encyklopedia terroryzmu 2004, 13).

In the $20^{\text {th }} \mathrm{c}$., terrorism became an accepted tactic of rebellion, especially in developing countries in postcolonial areas of Africa and South Asia, where the targets of attacks are visitors. In developed countries, the largest and most active terrorist organizations are
ETA (Basque Homeland and Freedom) and the IRA (Irish Republican Army), who also attack tourism sites. In 1996, ETA started to attack tourism destinations in Spain, including Majorca, and the IRA planted bombs at entertainment centres and restaurants on the mainland of Great Britain. Since the 1970s, the FLNC (Corsica National Liberation Front) has been attacking tourism resorts in Corsica.

In the 1960s and 1970s, Palestinian organizations became interested in air transport, sports events and tourism centres as easy international targets in the war with Israel. Attacks on Israeli tourism sites are still common (mostly in Jerusalem, Tel Aviv and Haifa). The beginning of modern international terrorism was marked by the hijacking of an Israeli plane flying from Rome to Tel Aviv, on 22 July 1968, by the Popular Front for the Liberation of Palestine (PFLP). Planes had been hijacked before, but in that particular case the terrorists' aim was to voice their own 
revolutionary propaganda. This modern tactic became a precedent repeated many times in following years.

The next wave of terror was connected with the growth of Islamic fundamentalism, whose main centre at the end of the 1970s was Iran. Similar activity was started by groups in Latin America and South Asia, who attacked tourism destinations or kidnapped tourists for publicity or to gain money for weapons. Tourists were frequently abducted by narcotic cartels in their war with the authorities.

For ten years, starting from 1975, ASALA (Armenian Secret Army for the Liberation of Armenia) attacked airline offices. In the 1990s, attacks were organized in Turkey (earlier also in Cyprus) and included abductions of tourists, or attacks on hotels and restaurants in holiday resorts, by members of the Kurdistan Workers' Party (PKK). In Egypt, in the 1990s, tourists were one of the main targets of Islamic terrorism. Despite the fundamentalists' traditional hostility towards 'western culture', seen as invading Islamic lands, the tourism sector is one of the major sources of income in Egypt. In October 1992, Islamic militants ambushed a tourist coach, killing one and injuring several others. The woman killed was the first foreigner to be murdered in Egypt in the 1990s; it was the beginning of a series of attacks on foreign tourists which were to make the Egyptian militants fighting against Hosni Mubarak's regime famous.

In March 1993, Islamists ordered all foreigners to leave the country. They started to attack tourists following a plan to break the country's economy and overthrow the government. Acts of violence took place during cruises on the Nile, in Cairo (e.g. in April, Islamic fundamentalists shot 18 Greek tourists in front of a hotel in Hurghada in Upper Egypt, because they mistook them for an Israeli group). Between 1992-7, over 90 foreigners were killed in Egypt. In 1993, one year after the campaign of terror began, income generated by tourism decreased by half, i.e. by 1.5 billion dollars (Encyklopedia Terroryzmu 2002, 403). The bloodiest attacks in Egypt took place in Luxor (17th November 1997 members of an Islamic Group attacked tourists in front of the Deir-el-Bahari shrines, as a result of which 62 people died), Taba (October 2004 - 34 victims of bomb attacks) and Sharm elSheikh (23 July 2005 - 88 died and over 200 were injured in bomb attacks).

Attacks on tourists have taken place in other parts of the world as well. On 16 ${ }^{\text {th }}$ May 2003, in Casablanca, Morocco, 33 civilians died, including foreign tourists, due to a series of suicide bomb attacks by terrorists from the Salafia Jihadia group. On $18^{\text {th }}$ January 2012, armed assailants in the north of Ethiopia attacked a group of European tourists, killing five, injuring two and kidnapping two. In press archives a lot of information about terrorist attacks on tourists or their abductions can be found, e.g. on Bali (bomb attacks in 2002), in Islamabad, Bombay and many other parts of the world where European tourists have been attacked by Islamic fundamentalists who wanted to frighten and discourage them from coming. A recent example of an area excluded from tourism use is the major tourism attraction in Pakistan - the Swat Valley which became one of the most important targets for $\mathrm{Al}$ Qaeda. In this way, the famous area of high-mountain trekking in northern Pakistan and the gate to the highest parts of the Himalayas was closed to tourism. The most tragic terrorist attack on Himalayan climbers in history took place in June 2013 at the Nanga Parbat base camp, which brought death to ten foreigners.

The most common terrorist strategy is the bomb attack, but in the 1970s other common methods included abducting hostages and hijacking planes or ships giving terrorists access to the mass media (Table 2).

The most spectacular abduction of hostages was the hijacking of five planes and blowing three of them up by the Popular Front for the Liberation of Palestine (PFLP) at Dawson's Field Airport in Jordan, in 1970, or the hijacking of the tourist ship, Achille Lauro, in the Mediterranean Sea in 1985.

In 1968 - 72 Palestinian terrorists hijacked 12 planes. Between 1969-81 there were over 550 cases of hijacking globally (Encyklopedia terroryzmu 2002, 225-226), many of which involved tourists. The number of hijacks decreased in the second half of the 1980s, mostly due to advances in aviation safety measures. Between 1969-94, 850 planes were hijacked, 50,000 people suffered, including 600 that died (STRZEMIENIECKI 1994, 51).

Most attacks on tourists have taken place in the poorest countries of the world, where tourism plays a key role in the economy. Wanting to discourage tourists from visiting the country, terrorists also hamper the economic and social development of a given region at the same time. International tourism is a sector based on interpersonal contacts and a dialogue between cultures. Success in tourism requires political stability, peace and security, which is why international terrorism brings negative economic, political and social effects, especially as regards international tourism (BACHVAROV \& NAPIERAEA 2002). This is confirmed by examples of the largest terrorist attacks directly or indirectly affecting a tourism economy. The turn of the millenium brought the bloodiest acts of terror, such as the attacks in Egypt in the 1990s and in 2004-5; the most tragic terrorist attack in history with the use of passenger planes in September 2001 in the USA; or the most atrocious attacks in contemporary Europe - in Madrid in 2004 and in London, in 2005. 
$\mathrm{T}$ a b l e 2. Examples of terrorist attacks on passenger planes and airport terminals in which tourists were the victims

\begin{tabular}{|c|c|c|}
\hline Date & Name of airline/airport & Description (terrorist group) \\
\hline $12 / 10 / 1967$ & Cyprus Airways & $\begin{array}{l}\text { Plane crash (de Havilland DH } 106 \text { Comet, flight 284) as a result of a bomb } \\
\text { explosion }\end{array}$ \\
\hline $23 / 7 / 1968$ & $\mathrm{El} \mathrm{Al}$ & The first Israeli plane hijacking (PFLP) \\
\hline $21 / 2 / 1970$ & Swissair & $\begin{array}{l}\text { Plane crash (Convair 990, flight 330), as a result of a bomb explosion in the } \\
\text { cargo hold (PFLP) }\end{array}$ \\
\hline $6-9 / 9 / 1970$ & El Al, Swissair, BOAC, TWA, Pan Am & $\begin{array}{l}\text { Hijacking } 5 \text { planes and blowing up } 3 \text { at Dawson's Field Airport in Jordan } \\
\text { (PFLP) }\end{array}$ \\
\hline 26/1/1972 & Jugoslovenski Aerotransport, & $\begin{array}{l}\text { Plain crash (McDonnell Douglas DC-9) as a result of a bomb explosion in the } \\
\text { cargo hold (Ustase - Croatian Revolutionary Movement) }\end{array}$ \\
\hline 30/5/1972 & Lod (Israel) & Lod Airport massacre (Japanese Red Army) \\
\hline $7 / 9 / 1974$ & TWA & Plane crash as a result of a bomb explosion (PFLP) \\
\hline $27 / 6 / 1976$ & Air France & Hijacking Airbus A-300, flight 139 (PFLP) \\
\hline 13/10/1977 & Lufthansa & Hijacking Boeing 737 (PFLP) \\
\hline $12 / 2 / 1979$ & Air Rhodesia & Vickers Viscount, flight 825 shot down (ZIPRA) \\
\hline $7 / 8 / 1982$ & Ankara (Turkey) & Planting a bomb at Ankara airport (ASALA) \\
\hline 23/6/1985 & Air India & $\begin{array}{l}\text { Plane crash (Boeing 747, flight 182) as a result of a bomb explosion (Babbar } \\
\text { Khalsa) }\end{array}$ \\
\hline $23 / 11 / 1985$ & Egypt Air & Hijacking a plane (Abu Nidala) \\
\hline $27 / 12 / 1985$ & Vienna (Austria), Rome (Italy) & Attacks on airports (Abu Nidala) \\
\hline $25 / 12 / 1986$ & Iraqi Airways & Hijacking and plane crash \\
\hline 29/11/1986 & Korean Air & $\begin{array}{l}\text { Plane crash (Boeing 747, flight } 858 \text { ) as a result of a bomb explosion (North } \\
\text { Korean agents) }\end{array}$ \\
\hline $21 / 12 / 1988$ & $\begin{array}{l}\text { Pan American World Airways } \\
\text { (Lockerbie) }\end{array}$ & $\begin{array}{l}\text { Plane crash (Boeing 747, flight 103), as a result of a bomb explosion (Libyan } \\
\text { agents) }\end{array}$ \\
\hline 19/9/1989 & UTA & $\begin{array}{l}\text { Plane crash (McDonnell Douglas DC-10, flight 772), as a result of a bomb } \\
\text { explosion (Libya) }\end{array}$ \\
\hline 24/12/1994 & Air France & Plane hijacking (Armed Islamic Group of Algeria) \\
\hline $23 / 11 / 1996$ & Ethiopian Airlines & Hijacking and plane crash (Boeing 767, flight 961) (Ethiopian terrorists) \\
\hline $11 / 9 / 2001$ & United Airlines, American Airlines & $\begin{array}{l}\text { Hijacking } 4 \text { planes belonging to American airlines and crashing them (Al } \\
\text { Qaeda) }\end{array}$ \\
\hline
\end{tabular}

So u r c e: author's compilation.

The results of a study conducted in Jordan among a group of foreign tourists from six continents (ALSARAYREH, JAWABREH \& HELALAT 2010, 157), point to political instability as an important factor affecting tourism. Wars between countries are destructive not only for the tourism economy of those countries, but also for those neighbouring, as with the wars in the Persian Gulf in 1991 and 2003. Tourism in Iraq was nearly totally paralyzed, but neighbouring countries such as Jordan and Syria were affected as well. Similarly, the unstable situations in Palestine, Syria and Iran reduce tourism in Israel. Apart from direct dangers to tourists, the destruction of tourism infrastructure and historical attractions, conflicts and acts of terror have a long-term effect on the image of the country or region. Tourism is always one of the first victims of armed conflict and acts of violence, as well as one of the main economic sectors affected by war, terrorist activity or political instability. Referring to the results of the study mentioned above, $78 \%$ of respondents enquired about the political situation in a country before a visit, and $61 \%$ took the political warnings not to travel to a given country during the crisis seriously.

Measurable benefits of attacks on tourists include the following: a guarantee of publicity; simultaneously hampering the development of the tourism sector and the whole economy; causing social tensions and undermining the position of authorities; lack of risk of losing the support of the local population due to the unacceptable and objectionable tourism behaviour resulting from cultural differences; drawing public attention to inequality between developed and developing countries, symbolized by the luxurious hotel facilities. Finally, the tourism sector is a relatively easy target of attack.

Terrorist attacks on tourists may be divided according to the site - an attack takes place at a recreational destination or in the transit zone between place of permanent residence and place of holiday stay (e.g. at airports or on means of transport); the target - during the attack the tourist is a consciously selected target or an incidental victim; while information about the attack holds up or reduces tourism at a site where it has happened before. 
A tourist is often an incidental victim of an attack. It may happen, however, that terrorists attack a group of tourists they had selected earlier, in order to gain specific benefits, frequently financial (abduction or blackmail for ransom). This usually happens in countries where conflicts have an economic, ethnic, political or religious background, as in Turkey, Israel, Palestine, the Middle East and Africa; Peru, Mexico and other countries of Latin America; Sri Lanka, the Philippines and other Asian countries.

The duty to warn tourists against danger was stated in the Global Code of Ethics for Tourism, which was approved during the $13^{\text {th }}$ General Assembly of the World Tourism Organization in Santiago, in 1999, in the A/RES/406 resolution. Official recognition by the UN General Assembly came on 21 ${ }^{\text {st }}$ December 2001, through the UN A/RES/56/212 resolution. It is a set of principles, whose purpose is to guide stakeholders participating in tourism development, such as state administration, local communities, tourism organizations, as well as tourists themselves, so that development is steady and responsible. The Code of Ethics refers to trade, security and humanitarian issues which influence tourism in a variety of ways. The authorities are responsible for ensuring security for tourists and visitors and their property. They should be particularly concerned about the security of foreign tourists who are at particular danger and provide them with easy access to information, protection, safety, security and help should such a need arise. Each attack, assault, abduction or threat to tourists or those employed in tourism, as well as purposeful destruction of tourism facilities, and cultural or natural heritage should be severely punished according to the law of a given country (Global Code of Ethics for Tourism, article 1, point 4).

Even when proper safety measures in the travel and tourism sector are kept, the danger of terrorism cannot be eliminated completely. Properly trained services may certainly help relieve the social and economic consequences of terrorist attacks. At the same time, it is important to strengthen and popularize the positive effects of tourism, such as the financial benefits to both the local population and the socio-economic system of the state that need to be supported in order to achieve political and economic stabilization. Travel and tourism weaken the factors leading to terrorism by supporting socio-economic development, creating employment opportunities and supporting mutual understanding and tolerance.

\section{REMEMBRANCE OF GENOCIDE AND TERROR AS A TOURISM STIMULATOR}

B. BOLECHÓW $(2002,17)$ draws attention to the subjective understanding of the innocence and guilt of the victims of terror. The guilty may be either tourists, because they support a regime financially, or other groups, as victims of ethnicity or social class. Some forms of terrorism involve attacking those who are not directly involved in conflict, but involvement has been taken by supporting the economy by visiting a given country. For some people someone may be a terrorist, while for others - a freedom fighter. Looking from this angle, sites of terror may be monuments to crime or to glory at the same time. It is very difficult to comprehend terrorism, although in Western thinking it is clearly a crime.

Terror policy is well thought out and long-term, used by a state on its own territory through special institutions, in order to reach certain political goals. Elements of terror include arrests, deportations, tortures, executions, etc, even violation of human rights on a massive scale (genocide). Such policy is sometimes part of the official interpretation of a state's ideology, supported by the law (BOLECHÓw 2002, 27). Terror produces remembrance sites which commemorate crimes; in time museums, mausoleums and other such places, visited by the victims' families, local people or tourists for differing reasons.

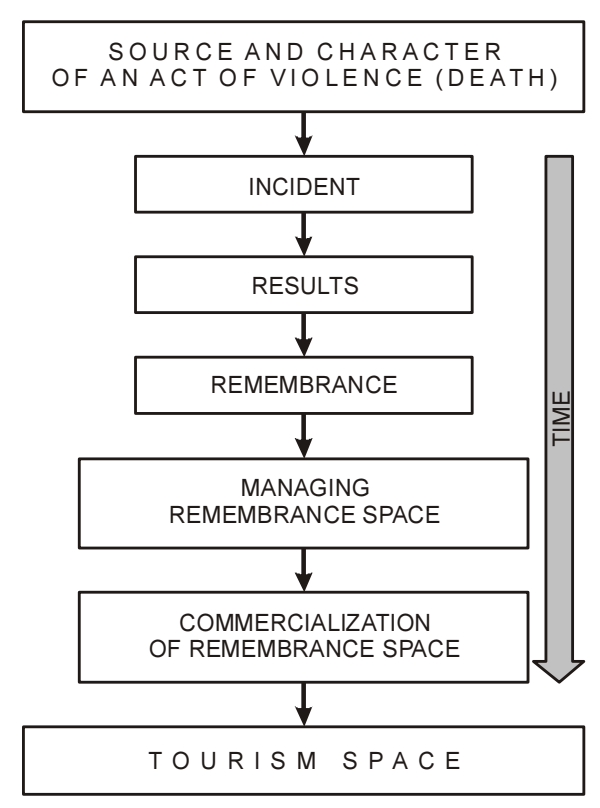

Fig. 2. Tourism use of an act of violence across time Source: author 
Travelling to places historically connected with war became popular as early as the $19^{\text {th }}$ c. However, it was not until the second half of the $20^{\text {th }} \mathrm{c}$. that managers of tourism space and the tourists themselves started to treat cemeteries, monuments and sites documenting acts of violence as tourism attractions. In order to provide a memorial to terror or other crime, remembrance space is managed, which may undergo commercialization and be transformed into tourism space and a tourism product (Fig. 2).

Recent decades have brought an unusual fashion for memorial museums. Their aim is to pay homage, commemorate, document, as well as study violence (Williams 2007). In Europe, there are remembrance sites which commemorate the victims of World War II, e.g. Auschwitz-Birkenau State Museum in Oświęcim, the former prisoner-of-war camp (stalag) on Święty Krzyż in the Świętokrzyskie Mountains, or the recently opened Martyrdom of Polish Villages Mausoleum in Michniów. In the 1990s, after the political and economic transformation, 'halls of memory' appeared devoted to Stalinism (e.g. History Museum of the City of Kraków with its permanent exhibition entitled 'Krakovian people and the terror of 1939-1945-1956', and the museums of the Polish Underground State's armed struggle (such as the modern, interactive Museum of the Warsaw Uprising). However, no central museum devoted to the crimes of Stalinism has been organized in Poland yet.

Memorial museums concerning extermination and genocide are quite common, as society is interested in their heritage and tragic history. The most interesting places of this kind, which are at the same time important tourism destinations, include the Yad Vashem Holocaust History Museum in Tel Aviv (Israel); the Tsitsernakaberd Museum of the Armenian Genocide (Armenia); the Fields of Death - a complex of commemorative monuments, museums and parks in Cambodia (e.g. in Tuol Sleng and Choeung Ek); Kigali Memorial Center in Rwanda; and the CemeteryMonument commemorating the victims of the Srebrenica massacre in Potočary (the Balkans). The Topography of Terror Documentation Centre (Topographie des Terrors) in Berlin commemorates the victims of Gestapo and SS. In Budapest, we can find the Museum of Communist Repressions - the House of Terror (Terror Háza Múzeum), commemorating the victims of the totalitarian system in Hungary in 194556. The museum and monument of 'Red Terror' (Red Terror Martyrs Memorial Museum) in Addis Ababa, Ethiopia commemorates the victims of the military junta from 1974-8.

The museum of Hezbollah terrorist technology in Mlit, Lebanon (Hezbollah's Terror Tech Museum) is a modern museum presenting the terrorist and armed activity of Hezbollah. The Counter-terrorism Education
Learning Lab opened in Denver, USA in 2009, is a modern centre devoted to anti-terrorist activity. The Oklahoma City National Memorial is dedicated to the victims of the bomb attack in 1995 and displays original exhibits from the tragedy. Currently, a 9/11 Memorial is being built to commemorate the victims of the attack on the World Trade Centre in New York on $11^{\text {th }}$ September 2001 and $26^{\text {th }}$ February 1993.

The truly $21^{\text {st }}$ century modern, interactive museum collects souvenirs and artefacts, documents events, commemorates victims, and educates - often by means of the most modern audio-visual technology. It is the form of presentation and the educational role that make these museums tourism attractions, seen as tourism products or elements of a larger one.

An interest in places documenting acts of mass murder and terrorism originates from the needs to be satisfied during a visit. It is usually a combination of the need to learn about heritage and cultural assets and a need to learn historical facts i.e. the cognitive and educational factor. Another motivation is emotional, both in the sphere of the sacred (identification with the tragedy and suffering of the victims) and the profane (experiencing fear and strong psychological stimuli through information, image and sound). Interest in death comes from its absence in the everyday life of an average tourist, however it is often featured in the media, films and books, thus arousing conscious or unconscious fascination with the problem.

In Poland it is hard to find places documenting contemporary terrorism, apart from a large number of places commemorating Nazi terror and Stalinism (ŁABUSZEWSKI 2012). The museums which document terror and genocide include those organized at the site of former concentration, extermination and POW camps. The best-known museum of this type in Poland is the Auschwitz-Birkenau National Museum in Oświęcim, presenting not only evidence of genocide and the extermination of the Jewish population (Shoah), but also the methods of terror used against civilians by the Nazis.

The study of motivations for visiting the AuschwitzBirkenau Museum (BERBEKA ed. 2012) validates the earlier statements. Half of the respondents confirmed that the museum is a stop en route in a tourism trip and pointed to the considerable tourism attractiveness of the site as well as its importance as a tourism product, increasing the tourism competitiveness of the Małopolska region. The majority of respondents mentioned the need to learn about the history of the camp, and pay homage to the victims as their motivation for the visit. As for post-visit emotions, tourists usually mentioned feelings of sadness, reflection, and at the same time respect for life and a stronger sensitivity to both human suffering and genocide itself. The results of this study confirm 
both the pedagogical and the andragogical effect of a tourism visit in a historical death space.

\section{GENOCIDE AND TERROR AS OBJECTS OF TOURISM INTEREST}

We should not ignore the fact that people differ in their opinions about travelling to sites connected with acts of terror and genocide for tourism purposes. We must also remember the commercial use of the effects of terror and genocide for purposes which are not always approved of. Unfortunately, tourism also generates thanatourism dysfunctions, possibly due to a superficial knowledge of a given death space, being filled with negative emotions and not wanted. Death space may also be seen as a place of contact with a pop-cultural image of death. Tourism may lead to excessive and undesirable exploitation of this space, its reification and profanation.

How death is presented, and historical facts narrated, is extremely important for the interpretation of the event and the visited site. The authenticity of the message about death, and the reaction to it as a result of receiving outside stimuli, is highly important for an understanding of the causes and results of a given death (STONE 2012). In visited death spaces, death is presented so that the tourist 'consumes' it in a particular way through his/her experience. By providing proper narration and its setting, the organizer of a 'death remembrance space' may pursue goals set earlier. Depending on whether the goals are educational or entertainment-oriented, the form of the message will be different, though each time it may be focused on triggering off certain reactions, often severe such as shock, disgust, fear, sadness, etc. At sites documenting terror and genocide, the educational message is important making the tourist aware in what conditions the crime was committed and what it involved. The goal of passing this information is to teach history, preserve the event in memory, but at the same time to develop certain social attitudes. It is naturally controversial to point to the entertainment aspect of the motivation to visit such places. However, many such visits take place during longer recreational stays or tourism trips, and the visited sites of remembrance - museums - are treated as tourism attractions or elements of larger tourism products. Ignoring the ethical aspect, places like Auschwitz, Ground Zero, or Toul Sleng are can be visited as an element of 'dark entertainment' (STONE 2009).

Organizing educational classes in given death spaces reinforces the historical, religious or social message, as well as a tourist's world view (TANAŚ
2011). Learning history at sites which commemorate death is certainly a tourism activity because learning about cultural heritage takes place through direct contact with a symbolic space. In this way, it is possible to enhance the building of national identity and develop patriotic attitudes. From the pedagogical and educational perspective, the aim of cognitive visits to a death space is to raise an individual's awareness by confronting behavioural patterns with death and its symbolism (TANAŚ 2012). A result of this may be an understanding of the need to organize tourism infrastructure in order to propagate historical knowledge, as well as an understanding of the activity of institutions working for the protection and preservation of cultural heritage and the memory of tragic events.

\section{CONCLUSIONS}

The author has considered the influence of acts of terror and war crimes on both the development of tourism, or a lack of it. On the one hand, terrorism hampers the development of tourism space and the tourism economy. It reduces or prevents tourism in areas where tourists suffer from acts of violence. With time, however, the crime and the memory of the victims may become an impulse to make commemorative, cognitive and other visits to remembrance spaces a part of tourism.

The examples of terrorist attacks quoted in the article, where tourists were incidental or consciously selected victims, point to the gravity of the problem in areas which are unstable politically and economically. Terrorism affects economic development and decreases tourism interest in areas which cannot guarantee safety to visitors, but which may offer outstanding recreational and cognitive assets. Unfortunately, statistics and the current global political situation show that many attractive tourism areas are or probably will be inaccessible to tourists. At the same time, new tourism products which are based on death as an element of cultural and historical heritage, set in death spaces, meet the expectations of a variety of groups, determining tourism potential in some areas.

\section{BIBLIOGRAFIA}

AlsARAYREH M., JAWABREH O., Helalat M., 2010, The Influence of Terrorism on the International Tourism Activities, European Journal of Social Sciences, 13/1, pp. 145-160.

BACZWAROW M., NAPIERAŁA T., 2002, Wpływ wydarzeń 11 września 2001 r. na turystykę światową, Turystyka i Hotelarstwo, 1, pp. 75-90. 
BEECH J., 2009, Genocide tourism, [in:] R. Sharpley, P.R. Stone (eds.), The darker side of travel: The theory and practice of dark tourism, Channel View Publications, Bristol, pp. 207-223.

BERBEKA J. (ed.), 2012, Turystyka martyrologiczna w Polsce na przykładzie Państwowego Muzeum Auschwitz-Birkenau, Proksenia, Kraków, 177 pp.

BOLECHÓW B., 2002, Terroryzm w świecie podwubiegunowym, Wyd. Adam Marszałek, Toruń, 539 pp.

BRUNETEAU B., 2005, Wiek ludobójstwa, Oficyna Wydawnicza „Mówią Wieki", Warszawa, 224 pp.

EDMONDS CH., MAK J., 2006, Terrorism and Tourism in the Asia Pacific Region: Is Travel and Tourism in a New World after 9/11?, East-West Center Working Papers. Economics Series, 86, pp. 29.

Encyklopedia terroryzmu, Muza SA, Wyd. Bellona, Warszawa, $745 \mathrm{pp}$.

Globalny kodeks etyki w turystyce (Global Code of Ethics for Tourism), rezolucja A/RES/406(XIII), Santiago, Chile, 27.09.-1.10.1999.

LENNON J., Foley M., 2000, Dark tourism: The attraction of death and disaster, Continuum, London, $184 \mathrm{pp}$.

ŁABUSZEWSKI T. (ed.), 2012, Śladami zbrodni. Przewodnik po miejscach represji komunistycznych lat 1944-1956, IPN, Warszawa, $632 \mathrm{pp}$.

SHARPLEY R., STONE P.R. (eds.), 2009, The Darker Side of Travel: The Theory and Practice of Dark Tourism, Aspects of Tourism Series, Channel View Publications, Bristol, 275 pp.
SEATON A., 1996, Guided by the dark: From thanatopsis to thanatourism, International Journal of Heritage Studies, 2(4), pp. 234-244.

STONE P.R., 2009, Dark Tourism: Morality and New Moral Spaces, [in:] R. Sharpley, P.R. Stone (eds.), The darker side of travel: The theory and practice of dark tourism, Channel View Publications, Bristol, pp. 56-74.

STONE P.R., 2011, Dark tourism: towards a new post-disciplinary research agenda, International Journal of Tourism Anthropology, 1(3/4), pp. 318-332.

STONE P.R., 2012, Dark Tourism and Significant Other Death: Towards a model of mortality mediation, Annals of Tourism Research, 39(3), pp. 1565-1587.

STRZEMIENIECKI R., 1994, Powrót bombardierów, Wprost, 11/09, pp. 51.

TANAŚ S., 2006, Tanatoturystyka - kontrowersyjne oblicze turystyki kulturowej, Peregrinus Cracoviensis, 17.

TANAŚ S., 2011, Pamięć $i$ śmierć w przestrzeni turystycznej, [in:] J. Kolbuszewski (ed.), Problemy wspótczesnej tanatologii, 15, Prace Wrocławskiego Towarzystwa Naukowego, Seria A, 267, pp. 129-137.

TANAŚ S., 2012, Edukacyjne i wychowawcze aspekty tanatoturystyki, [in:] Z. Rudnicki (ed.), Ars moriendi. Ars vivendi. Ars educandi, Wyd. Naukowe UAM, Poznań, pp. 427-442.

UNWTO Tourism Highlights, 2013, Edition.

Williams P., 2007, Memorial Museums: The Global Rush to Commemorate Atrocities, Berg Publishers, pp. 236. 